\title{
Analysis Approach of How University Automotive Competitions Help Students to Accelerate Their Automotive Engineer Profile
}

\author{
Francisco J. Sánchez-Alejo, Miguel A. Álvarez, \\ Francisco Aparicio and José M. López \\ University Institute for Automobile Research, INSIA, Polytechnic University of Madrid
}

Spain

\section{Introduction}

Today, the world's leading universities in the world not only are concerned about the importance of enhancing student's personal and professional skills, but most of them are modifying their study's programs to adapt them to these new requirements (Aparicio et al., 2005), (Bowen et al., 2005) and (Chadha \& Nicholls, 2006).

Eeven though different definition can be found, skills are "a combination of knowledge, abilities and attitudes that are suited to particular circumstances" (European Parliament, 2006). On the other hand, skills can be understood as "the set of knowledge, abilities, behaviour and attitudes that favour work being done properly and which the organisation is interested in developing or recognising in its co-workers when it comes to achieving the company's strategic goals" (De Miguel et al., 2006).

Many years before the major of these universities became fully aware of the importance of promoting personal and professional skills among their students, companies in different sectors recognised the gap existing between university and business, and on some occasions proposed activities to try to narrow it.

For instance, in 1982 engineers from Ford, DaimlerChrysler and General Motors, grouped together in the SAE (Society of Automotive Engineers), in the United States, being aware of how little newly graduated engineers were adapted to automotive companies, designed a competition for universities throughout the world, which involved conceiving, designing, manufacturing and competing with a single seat formula-type vehicle under some strict rules. This competition was called Formula SAE.

These pioneers were of the opinion that this challenge would serve to accelerate engineering students' professional profiles, forcing them to work as part of a team, with high levels of communication, responsibility and motivation, forcing them to use in their work a large part of the knowledge acquired in their degree. Today, more than 200 universities of five continents compete at some of the tests that Formula SAE has round the world.

Since then, some other automotive competitions for engineering universities have come up, each of them with their specific objectives and rules. Shell Eco-marathon consists on the development of a vehicle able to cover the maximum distance with a litre of petrol. At Baja $\mathrm{SAE}$, engineering students are tasked to design and build an off-road vehicle that must 
survive on rough terrain. The World Solar Challenge is a solar-powered car race that covers more than $3.000 \mathrm{~km}$ in Australia. Due to the high expenses these competitions used to involve, that prevent lots of universities to take part on them, the latest competition created was called Formula Low-cost, which main objectives is the designing, manufacturing and competing with a go-kart build with less than $2.000 €$.

The mentioned competitions and some others, with their own peculiarities, constitute an educational experience that provides the students with a real-life exercise in design, manufacture and the business elements of automotive engineering. They teach them all about team working under schedule and cost pressure, with the illusion and challenge of competing against themselves and others. They demand total commitment, important personal effort, and involve many frustrations and challenges along the way, but the net result is the development of highly talented young engineers. It has been demonstrated that these challenges allow the participant to highly improve personal and professional skills as important as creativity, responsibility, solving conflicts, leadership, teamwork, etc.

These principles are in the scope of what political and educational authorities in major developed countries are proposing to modernize university studies and to meet the needs of companies in the automotive industry today and tomorrow (De Miguel et al., 2006), (Davies et al., 1999), (González \& Wagenaar, 2003), (Bologna Declaration, 1999).

Although the needs of this sector are not very different from the others, the dynamic character, competitiveness and technological challenges of the automotive industry make that the most demanded skills in new graduates are leadership and team motivation, responsibility at work and teamwork. Also highly rated are the capacity to innovate, and communication and negotiating skills (Sánchez et al., 2009).

\section{Description of six of the most representative automotive university competitions for engineers}

As it was mentioned before, today there are several automotive competitions oriented to undergraduate students in which the multidisciplinary groups of each university have to build a vehicle. Each competition has different educational objectives, as teamwork, leadership, innovation or problem solving, among others. The most important, for their educational goals, are shown on Table 1.

Although there are many differences between these competitions, all of them have in common the way the students do the work (with technical, schedule and budget requirements and constraints) and assume their responsibilities.

It should be noticed that the responsibility given to each student is real: each one is aware that a mistake by one of them is a mistake for the whole team. Equivalent responsibility would only be found in any company after some years of work. The students themselves even take it upon themselves to raise part of the financial resources needed, and it is they, under the supervision of the teachers, who manage these resources.

In the course of the educational experience carried out by taking part in these projects, planned with different teaching methods, the student must face up to specifically designed situations that will challenge them and promote their personal and professional skills. Some studies (Sánchez et al., 2009) have shown the different learning situations through which the students must pass, and the skills each experience helps to reinforce. 


\begin{tabular}{|c|c|c|c|}
\hline Competition & Evaluation & Main Event & Main Features \\
\hline Formula SAE & $\begin{array}{l}\text { - Design } \\
\text { - Cost } \\
\text { - Sales } \\
\text { - Vehicle } \\
\text { Performance }\end{array}$ & $22 \mathrm{~km}$ track & $\begin{array}{l}\text { - Engine limited to } 600 \mathrm{cc} \\
\text { - All air must pass through a } 20 \mathrm{~mm} \\
\text { restriction } \\
\text { - Restriction on vehicle overall } \\
\text { dimension }\end{array}$ \\
\hline Mini Baja SAE & $\begin{array}{l}\text { - Design } \\
\text { - Cost } \\
\text { - Sales } \\
\text { - Vehicle } \\
\text { Performance }\end{array}$ & $\begin{array}{l}\text { Maximum } \\
\text { distance } \\
\text { performed in } \\
4 \text { hour }\end{array}$ & $\begin{array}{l}\text { - Engine provide by organization } \\
\text { - Not to modify engine } \\
\text { - Restriction on vehicle overall } \\
\text { dimension }\end{array}$ \\
\hline Eco-Shell & $\begin{array}{l}\text { - Vehicle } \\
\text { Performance }\end{array}$ & $\begin{array}{l}22 \mathrm{~km} \text { to } \\
25 \mathrm{~km} \text { set } \\
\text { track }\end{array}$ & $\begin{array}{l}\text { - Several fuel possibilities supported } \\
\text { - Restriction on overall dimensions }\end{array}$ \\
\hline $\begin{array}{l}\text { Supermileage } \\
\text { SAE }\end{array}$ & $\begin{array}{l}\text { - Design } \\
\text { - Vehicle } \\
\text { Performance }\end{array}$ & $\begin{array}{l}15 \mathrm{~km} \text { oval } \\
\text { test track }\end{array}$ & $\begin{array}{l}\text { - Engine provide by organization } \\
\text { - Restriction to modify engine } \\
\text { - Travel a specified distant with } \\
\text { minimum fuel consumption }\end{array}$ \\
\hline $\begin{array}{l}\text { World Solar } \\
\text { Challenge }\end{array}$ & $\begin{array}{l}\text { - Vehicle } \\
\text { Performance }\end{array}$ & $\begin{array}{l}3.000 \mathrm{~km} \\
\text { distance }\end{array}$ & $\begin{array}{l}\text { - Only solar vehicles } \\
\text { - Restriction on overall dimensions }\end{array}$ \\
\hline $\begin{array}{l}\text { Formula Low } \\
\text { Cost }\end{array}$ & $\begin{array}{l}\text { - Design } \\
\text { - Cost } \\
\text { - Innovations } \\
\text { - Vehicle } \\
\text { Performance }\end{array}$ & $\begin{array}{l}60 \text { laps on set } \\
\text { course }\end{array}$ & $\begin{array}{l}\text { - Engine limited to } 12 \mathrm{kw} \\
\text { - Maximum budget of } 2000 € \\
\text { - Event to evaluate innovations }\end{array}$ \\
\hline
\end{tabular}

Table 1. Main characteristics of six competitions.

\subsection{The formula SAE competition}

Formula SAE is probably the automotive competition that poses the greatest challenge for students and, therefore, today is the largest university event round the world. (http://students.sae.org/competitions/formulaseries/).

To ensure uniformity and equal opportunities in the competition, the SAE sets strict standards as to the design and manufacture of the different vehicle parts, in addition to severe safety standards. In spite of this, the participants enjoy a wide autonomy and capacity to innovate, as can be seen in the differences between the prototypes developed by each university.

Teams must present a project as if it involved a company that manufactured 1000 vehicles per year for an amateur public competing at weekends, and with a cost of less than 25,000\$. The most important condition refers to vehicle power, restricted by engine cylinder capacity $\left(\right.$ maximum $600 \mathrm{~cm}^{3}$ ) and by a restricted air intake. Therefore, most machines use motorbike 


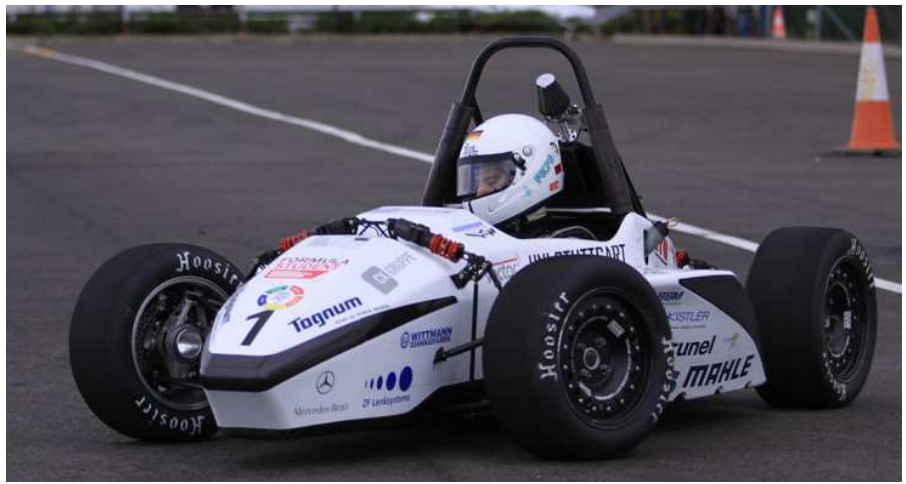

Fig. 1. Formula SAE car at competition.

engines which are standard engines of around $110 \mathrm{HP}$, but by restricting the air intake their capacity is reduced to around $70 \mathrm{HP}$ after appropriately designing of the intake and exhaust with fluid dynamics programs and after electronically changing the engine torque and power curves.

There are other restrictions, that are refered to vehicle size (minimum 1,520 mm wheelbase, and minimum $9 \mathrm{~m}$ slalom track pass), which means that the vehicles are around 2,700 to $3,000 \mathrm{~mm}$ long. There is also an exhaustive verification of the materials making up the chassis, and close attention is paid to safety and driving seat ergonomics.

The competition score cards are divided into two kinds: static and dynamic. Also, there are some preliminary tests that do not score, but need to be overcome in order to compete. Table 2 shows the tests together with a brief description of each one.

It is, therefore, an authentic engineering competition where in addition to vehicle speed and performance at track, the project and the product achieved are also appreciated. In this competition the students have a totally leading role. They have to organise themselves, find the resources needed, administer project time, costs, etc, and all this under the supervision and guidance of the teachers and the Faculty Advisor. They have to design and build the parts by hand (the fewer purchased the better), and four of them must finally drive the car. What is new about this project, apart from it being a new, innovative educational methodology where the vehicle is simply the means to get the best possible training, is the challenge posed to the students by having to take on and participate in an entire vehicle development life cycle. This can only be achieved by forming a strong working team, promoting active participation, the assumption of responsibilities, decision making and involvement in reaching a common objective. In exchange the student gets the satisfaction of being able to take the vehicle built by their own effort to an actual competition.

In 2009, more than 200 universities throughout the world took part in the Formula SAE. For this it has been necessary to extend the competitions to other countries, like England, where it is called Formula Student, Australia, etc, as well as the original in Michigan.

\subsection{The Baja SAE competition}

Baja SAE is a university competition whose aim is to improve the preparation and education of young engineers through an event that simulates a real engineering project where students have to design, manufacture, test, and compete with an off-road vehicle. (http://students.sae.org/competitions/bajasae/). 


\begin{tabular}{|c|c|c|}
\hline Events & Points & Description \\
\hline Preliminary tests & 0 & Pre-competition safety tests. \\
\hline $\begin{array}{l}\text { Technical } \\
\text { inspection }\end{array}$ & - & General check of car by judges. \\
\hline Tilt & - & $\begin{array}{l}\text { Car inclination up to } 60^{\circ} \text { checking its stability and that } \\
\text { no type of liquid is leaking. }\end{array}$ \\
\hline Brakes & - & $\begin{array}{l}\text { Simultaneous blocking of all four wheels after a brief } \\
\text { acceleration. }\end{array}$ \\
\hline Noise & - & $\begin{array}{l}\text { Check to ensure vehicle emits less than } 110 \mathrm{~dB} \text { under } \\
\text { certain acceleration conditions. }\end{array}$ \\
\hline Static & $\begin{array}{c}325 \text { in } \\
\text { total }\end{array}$ & $\begin{array}{l}\text { Presentations and oral defence in front of the judges of } \\
\text { technical solutions adopted. }\end{array}$ \\
\hline Design & 150 & $\begin{array}{l}\text { Technical defence of vehicle design and solutions } \\
\text { proposed. }\end{array}$ \\
\hline Presentation & 75 & $\begin{array}{l}\text { Marketing presentation, convincing the judges to choose } \\
\text { their car compared to the others. }\end{array}$ \\
\hline Costs & 100 & $\begin{array}{l}\text { Written report detailing cost of each part and component } \\
\text { of the unit built. }\end{array}$ \\
\hline Dynamic & $\begin{array}{l}675 \text { in } \\
\text { total }\end{array}$ & Different on-track trials with the single-seater. \\
\hline Acceleration & 75 & Cover $75 \mathrm{~m}$ on a straight run in the shortest possible time \\
\hline $\begin{array}{l}\text { Manoeuvrability } \\
\text { (Skidpad) }\end{array}$ & 50 & $\begin{array}{l}\text { Manoeuvrability to run a } 9 \text { metre circle in both } \\
\text { directions. }\end{array}$ \\
\hline Sprint & 150 & Quick lap of the circuit. \\
\hline Endurance & 350 & $\begin{array}{l}\text { Overall vehicle performance and reliability in } 22 \text { laps of } \\
\text { a circuit. }\end{array}$ \\
\hline Fuel & 50 & Minimum consumption in endurance trial \\
\hline Total & 1000 & \\
\hline
\end{tabular}

Table 2. Description of Formula SAE competition trials.

Teams have to assume that they have been hired by a manufacture firm to build an off-road vehicle capable of competing in any field. The restrictions are on the design of chassis, and the engine modifications are forbidden, as the engine is the same for all teams. Unlike Formula SAE standards these restrictions limit the design and innovation in these areas, leaving the engineer's imagination for other areas of the vehicle. This, in turn, results in a reduction in costs and activities compared with Formula SAE. The target for selling the prototype is the non-professional weekend racer, as well as the Formula SAE, and the teams must develop a product that has high performance in acceleration, traction, with common parts and easy maintenance. It is a competition that also simulates a case study of the life cycle of a vehicle, where students also have to get organized sponsorship for their project.

All the teams have the same 10HP engine, and it is not allowed to make any changes or modifications. The overall dimension of the vehicle is recommended to be around $2750 \mathrm{~mm}$, 
and the track is restricted to a maximum of $1900 \mathrm{~mm}$. The cage in the chassis is very limited in terms of innovation to ensure the safety at all situations, as in the event of rollover or impacting with another vehicle.

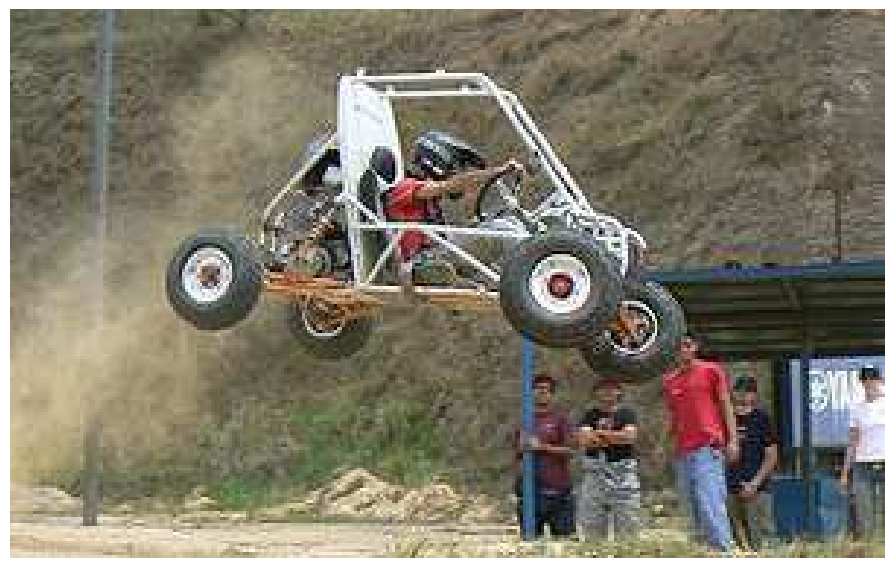

Fig. 2. Baja SAE vehicles have to overcome all kind of fields.

Judges positively value the manufacturing capacity with conventional tools that are available to anyone. Teams will be evaluated on design, and marketing costs (not all of Baja competitions own this event). In the dynamic performance, the students must demonstrate their ability to accelerate, steer, and drive the vehicle to finally be evaluated in endurance where they is allowed to repair the vehicle in the race if necessary. Table II shows the events with a brief description of each one.

Baja SAE competition began in 1976, and currently has 6 competitions in the USA, Brazil, South Africa and South Korea, and more than 250 universities are involved with more than 4000 students participating.

\subsection{Eco-Shell Marathon}

Eco-Shell Marathon is a university and college competition that has the goal to compete with more efficient vehicle for a given distance. There are two categories, one corresponding to futuristic vehicles where reducing drag and maximizing efficiency is the major premise and the second category corresponding to four-wheeled vehicle using conventional or alternative fuels. (http:/ / www.shell.com/home/content/ecomarathon/)

The rules limit the size in wheelbase, track and height of vehicles, chassis design (to ensure safety), the type of propulsion (it can be used combustion, fuel cell or solar) and fuel tank is limited to $30 \mathrm{~cm}^{3}$ to $250 \mathrm{~cm}^{3}$, limiting the engines size to use. The following list outlines the types of fuel that can be used:

- $\quad$ Shell Unleaded 95 (Europe \& Asia) / Shell Regular 87 (U.S.)

- Shell Diesell

- $\quad$ Liquefied Petroleum Gas (LPG)

- $\quad$ Shell Gas to Liquid (GTL 100\%)

- $\quad$ Fatty Acid Methyl Ester (100\% FAME)

- $\quad$ Ethanol E100 (100\% Ethanol)

- Hydrogen 


\begin{tabular}{|c|c|c|}
\hline Event & Points & Description \\
\hline Static Events - & $\begin{array}{l}300 \text { in } \\
\text { total }\end{array}$ & $\begin{array}{l}\text { Presentations and oral defence in front of the } \\
\text { judges }\end{array}$ \\
\hline $\begin{array}{l}\text { Design Report \& } \\
\text { Evaluation }\end{array}$ & 150 & $\begin{array}{l}\text { Technical defence of vehicle design and solutions } \\
\text { proposed }\end{array}$ \\
\hline $\begin{array}{l}\text { Cost Report \& Cost } \\
\text { Production }\end{array}$ & 100 & $\begin{array}{l}\text { Writing report dealing cost of each part and } \\
\text { component of the unit built }\end{array}$ \\
\hline Presentation & 50 & $\begin{array}{l}\text { Marketing presentation, convincing the judges to } \\
\text { choose their car. }\end{array}$ \\
\hline Dynamic Events - & $\begin{array}{c}700 \\
\text { points }\end{array}$ & Different on-track trials with the off-road vehicle \\
\hline Acceleration/Speed & 85 & $\begin{array}{l}\text { Cover } 30 \mathrm{~m} \text { o } 45 \mathrm{~m} \text { on a straight run in the shortest } \\
\text { possible time }\end{array}$ \\
\hline Traction/Hill Climb & 75 & $\begin{array}{l}\text { The traction event will be either hill climb or pulling } \\
\text { an object }\end{array}$ \\
\hline Manoeuvrability & 75 & $\begin{array}{l}\text { Manoeuvrability including tight turns, pylon } \\
\text { manoeuvres, ruts and bumps, drop-offs, sand, } \\
\text { rocks, gullies, logs, and inclines. }\end{array}$ \\
\hline Specialty Rock Crawl & 75 & $\begin{array}{l}\text { A special event to test the vehicle on unique off- } \\
\text { road conditions }\end{array}$ \\
\hline Endurance & 400 & Maximum distance performed in 4 hours \\
\hline Total Points & 1000 & \\
\hline
\end{tabular}

Table 3. Description of Formula Baja competition trials.

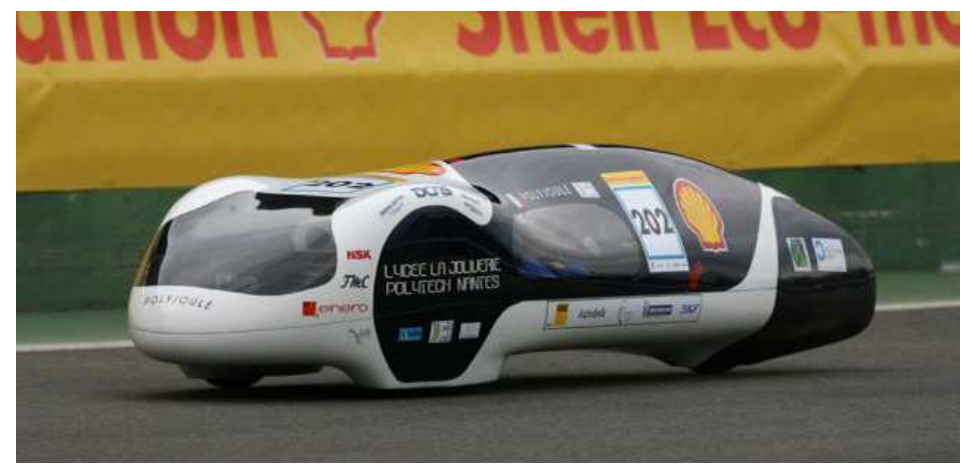

Fig. 3. Aerodynamics is an important goal at Ecoshell Marathon. 
Depending on the category in which they participate, vehicles must meet travel between 22 $\mathrm{km}$ or $25 \mathrm{~km}$. The assessment of efficiency is done in accordance with a table of equivalence developed by the competition.

The objective of the competition is to simulate a real art project where teams work for a year designing and building a vehicle. The event organizers also want students to integrate, design and develop a product that is sustainable, that controls the energy used and that is concern about environmental protection. This target causes that the greatest number of team efforts are focused in engines, transmissions and aerodynamics.

\subsection{Supermileage}

Supermileage's objective goes in the same line as the previous competition, that is, developing a single person, extremely high mileage vehicle that complies with the organization rules. The competition intention passes through encourage the fuel economy. (http://students.sae.org/competitions/supermileage/).

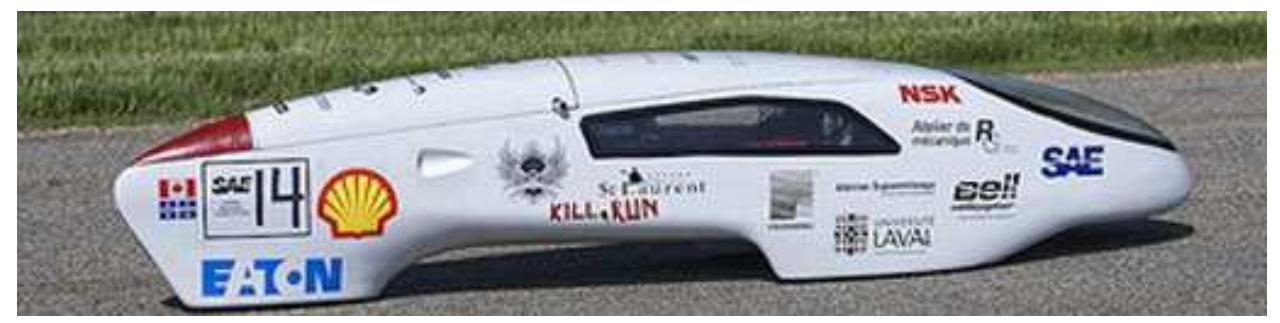

Fig. 4. Supermileage vehicle at competition.

Team's vehicles must be conceived, designed and manufactured by the team members without direct involvement from faculty and technical staff in the college/school or professionals in the motorsports community.

All the innovation and creativity of the teams is focused on consumption and weight reduction. The rules set restrictions on engine type, fuel used, chassis construction, and minimum driver mass allowed. Although in this competition there are no rules for vehicle dimension boundaries, which represents a plus to creativity, one of the technical inspections test, call manoeuvrability, has specific and defined turn radius and fix cone slalom distant, which are considered as rule restrictions.

The competition is divided into the design event and the performance run, as the other SAE competition series. At the design event the teams have to elaborate a report to describe theirs design decisions, and the students have to defend it in front a jury. The performance run consist on a race of $15 \mathrm{Km}$ in which the car is weighted before and after the completion of the track, calculating then the kilometres per litter of fuel, weighing them with the elapsed time.

\subsection{World solar challenge}

First promoted in 1987 by the adventurer Hans Tholstrup, World Solar Challenge began in Australia, and consists on building a solar vehicle with certain rules described in the technical regulations. The aim is to stimulate research into sustainable transportation. (http://www.globalgreenchallenge.com.au/). 


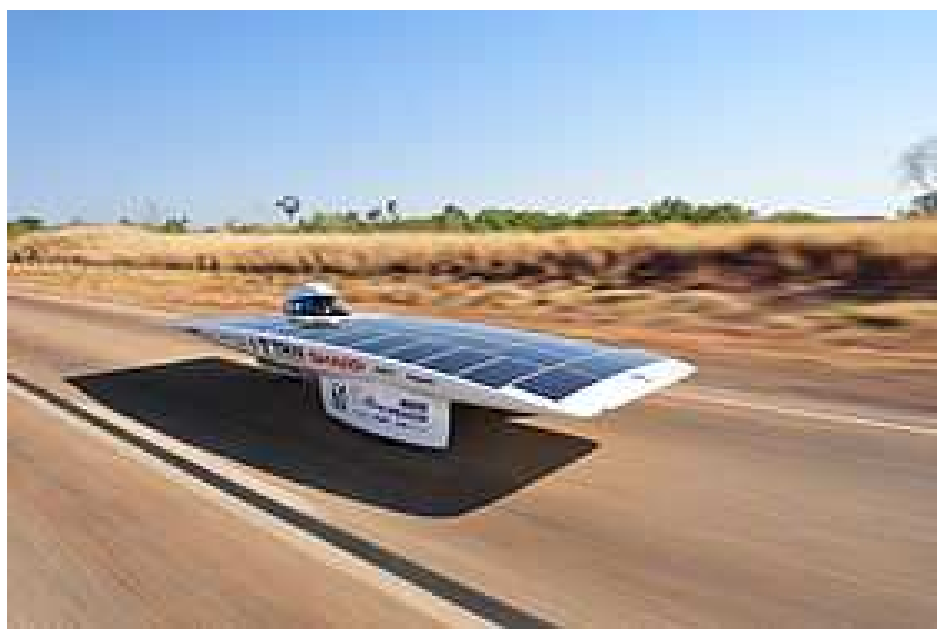

Fig. 5. WSC cars have large areas to place solar panels.

From an academic point of view, the goal is to encourage the students to put their efforts on developing a sustainable vehicle that is able to travel a distance of $3.000 \mathrm{~km}$ in the shortest time using only sunlight as fuel. The competition take place in Australia and it is sponsored by Australian administrations. It usually takes three days to complete the distance, and there are not other events to evaluate the design concepts, sales or management skills.

Teams are restricted by the overall vehicle dimensions, the solar array area, and the minimum driver's weigh. There are also some other rules about chassis design focused on ensuring the driver safety.

The competition has actually 32 participants in the university category, and most of them also participate in the eco-shell Marathon held in Europe.

\subsection{Formula Low Cost}

Formula Low Cost was created by the Institute of Automotive and Transport Engineering (ISAT) in Nevers (France) in 2008 with the aim of extend these kind of competitions to universities all around the world, regardless their economic possibilities, Low Cost Formula is a competition aimed at extending university engineering education through the construction of a kart type vehicle. The main difference with Formula SAE is the budget, which cannot exceed $2.000 €$ for its build, based on fixed prices of components. (http://www.kartlowcost.com/Presentation.html)

Teams have to assume they have been contracted to manufacture a vehicle whose main feature is that it has not suspension. The rules establish that they must design the chassis to ensure safety, and the materials are limited to steel and/or aluminum. The engine cannot exceed $12 \mathrm{KW}$ and are well worth the innovations that can be made. Although the size of vehicle is complete free, the possibilities with the 2,000€ budget restriction are limited.

As well as the other engineering competitions, teams valuation is done through a set of tests, both static (where it is evaluated the technical and cost features) and dynamic (where it is evaluated the track vehicle performance). The statics events have the aim to assess the designs, innovations and cost of the prototype. The dynamic events are composed of three: a classification, a sprint race (15 laps) and resistance (60 laps). 


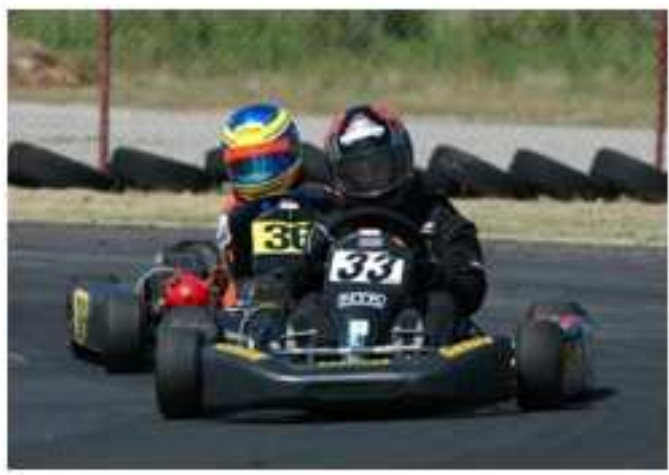

Fig. 6. Karting competition at Formula Low Cost s.

Formula Low Cost also provides an opportunity for students to participate throughout the life cycle of a real project, in order to prepare engineers to manage projects, budgets and learn to work as a part of a team. Table III shows the events with a brief description of each one.

\begin{tabular}{|c|c|c|}
\hline Event & Points & Description \\
\hline Static Events - & 478 in total & $\begin{array}{l}\text { Presentations and oral defence in front } \\
\text { of the judges }\end{array}$ \\
\hline Cost Report & 183 & $\begin{array}{l}\text { Writing report detailing cost of each part } \\
\text { and component of the unit built }\end{array}$ \\
\hline Innovations & 183 & Technical evaluation of innovations \\
\hline Design & 112 & $\begin{array}{l}\text { Technical defence of vehicle design and } \\
\text { solutions proposed }\end{array}$ \\
\hline Dynamic Events - & 441 points & $\begin{array}{l}\text { Different on-track trials with the off- } \\
\text { road vehicle }\end{array}$ \\
\hline Acceleration/Speed & 75 & $\begin{array}{l}\text { Cover a straight run in the shortest } \\
\text { possible time }\end{array}$ \\
\hline Sprint & 183 & $\begin{array}{l}\text { A event to classified the vehicle for the } \\
\text { main event }\end{array}$ \\
\hline Endurance & 183 & 60 laps to a circuit \\
\hline Total Points & 919 points & \\
\hline
\end{tabular}

Table 3. Description of Formula Low Cost competition trials

In a general view, Table 1 lists the main characteristics of these competitions. Some of them are focused on evaluating the engineering, product cost and sales skills, as are the SAE Series Events; some others are focused on developing an specific vehicle based on fuel 
efficiency using conventional or alternative fuels; and the newest competition, the Formula Low Cost, makes the costs the main restriction, and it is the only one with an specific event evaluating innovations.

Each competition present differences in team member's size, depending on the universities and work philosophy. Formula SAE and Mini Baja teams tend to be more numerous than the others, surely because of fewer restrictions and greater design possibilities.

The principal common characteristic or these competitions, and some other round the world, is that they represent a challenge for the students to overcome themselves and exchange experiences with students from five continents.

\section{An example of the activities performed at one of these competitions: the participation of the UPM on Formula SAE.}

UPMracing is the first Spanish Formula SAE competition team, and was founded on 2003 at the Madrid Polytechnic University, UPM. At that moment, a group of teachers and professors of the School of Industrial Engineering, ETSII-UPM, and researchers of the University Institute for Automobile Research, INSIA-UPM, selected this competition as the most complete. The team consisted of about 35 students from the final courses or ETSII and the Master's course in Automotive Engineering (Figure 7). In the years that followed, several students from other university schools joined in, like the Aeronautic Techniques and Industrial Techniques schools, what lead to important improvements in the performance (Figure 7).

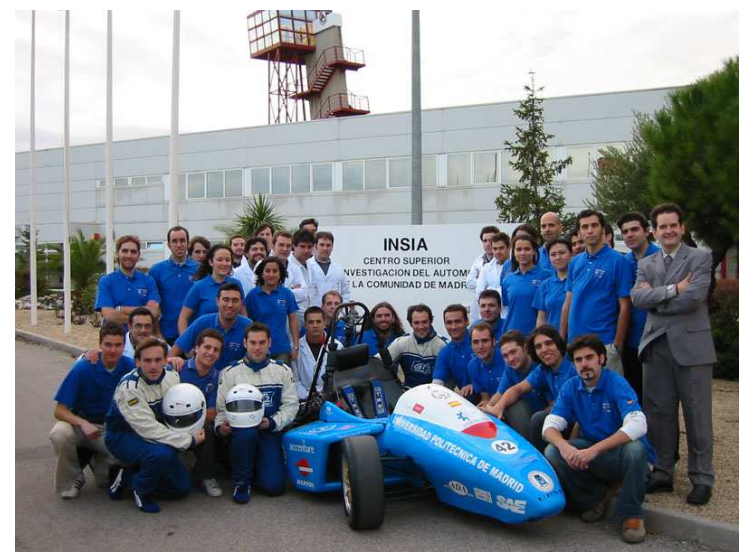

Fig. 7. The first team with the UPM-01 at INSIA-UPM.

When writing this article, UPMracing has accumulated seven years of experience with the same number of single-seaters built that have taken part in the $2004-2010$ editions of the Formula Student in England and Germany.

From the beginning, the team has had four principles that are a statement of the teaching method used:

- Learn by applying

- Learn by doing

- Learn in a team

- Learn by competing 
The members of the team have been organized in several departments according to the main systems of the vehicle, with the aim of reproduce similar conditions to the work carried out in real companies. These divisions are supervised by a small team of teachers, but the students have a great level of autonomy both on technical and organizational field.

\begin{tabular}{|c|c|c|c|c|c|c|c|c|c|c|c|c|c|c|c|c|}
\hline Learn & 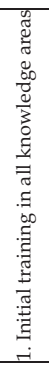 & 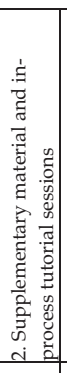 & 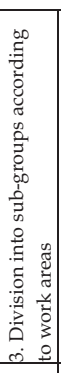 & 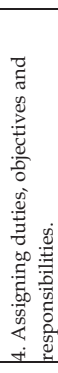 & 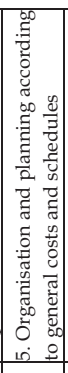 & 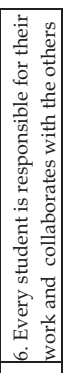 & 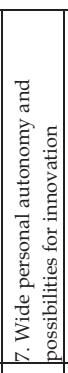 & 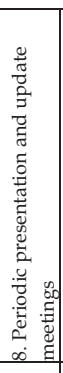 & 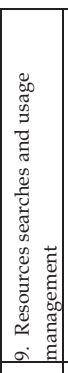 & 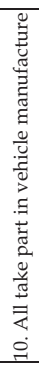 & 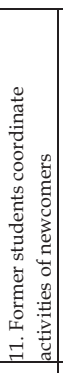 & 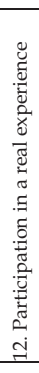 & 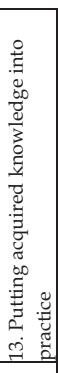 & 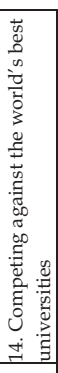 & 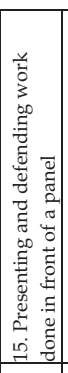 & 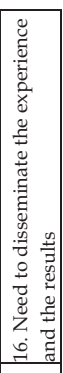 \\
\hline $\begin{array}{l}\text { 1. Ability to work as part } \\
\text { of a team }\end{array}$ & & & $x$ & $\mathrm{X}$ & $\mathrm{x}$ & $\mathrm{x}$ & & $\mathrm{X}$ & $\mathrm{X}$ & $x$ & $x$ & $x$ & & $\mathrm{x}$ & $\mathrm{X}$ & $x$ \\
\hline 2. Leadership qualities & & & $\mathrm{X}$ & $\mathrm{X}$ & $\mathrm{X}$ & $\mathrm{X}$ & & $X$ & $\mathrm{X}$ & $X$ & $\mathrm{X}$ & $X$ & & $\mathrm{X}$ & $\mathrm{X}$ & $X$ \\
\hline 3. Ability to motivate & & & $X$ & $\mathrm{X}$ & $\mathrm{X}$ & $\mathrm{X}$ & & $\mathrm{X}$ & & $X$ & $\mathrm{X}$ & $\mathrm{X}$ & & $\mathrm{X}$ & $\mathrm{X}$ & $\mathrm{X}$ \\
\hline $\begin{array}{l}\text { 4. Capacity for } \\
\text { responsibility and } \\
\text { commitment } \\
\end{array}$ & & $\mathrm{X}$ & $\mathrm{X}$ & $\mathrm{x}$ & $\mathrm{x}$ & $x$ & $x$ & $\mathrm{X}$ & $\mathrm{X}$ & $x$ & $\mathrm{X}$ & $x$ & & $\mathrm{X}$ & $\mathrm{x}$ & $\mathrm{X}$ \\
\hline 5. Capacity for innovation & & & & $\mathrm{X}$ & & $\mathrm{X}$ & $\mathrm{X}$ & & & $\mathrm{X}$ & & $\mathrm{X}$ & $\mathrm{X}$ & $\mathrm{X}$ & & \\
\hline 6. Negotiating skills & & & $\mathrm{X}$ & $X$ & $x$ & $\mathrm{X}$ & $X$ & $x$ & $\mathrm{X}$ & $X$ & $X$ & $\mathrm{X}$ & & $X$ & $X$ & 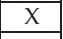 \\
\hline $\begin{array}{l}\text { 7. Capacity for self- } \\
\text { motivation } \\
\end{array}$ & $\mathrm{X}$ & $\mathrm{X}$ & $\mathrm{X}$ & $\mathrm{X}$ & & $\mathrm{X}$ & $\mathrm{X}$ & & $\mathrm{X}$ & & & & & $x$ & $\mathrm{X}$ & \\
\hline 8. Analytical skills & $\mathrm{X}$ & $\mathrm{X}$ & $\mathrm{X}$ & $\mathrm{X}$ & $\mathrm{X}$ & $\mathrm{X}$ & $\mathrm{X}$ & $\mathrm{X}$ & $\mathrm{X}$ & & & & $\mathrm{X}$ & $\mathrm{X}$ & & \\
\hline 9. Ability to summarise & & & & $\mathrm{X}$ & $\mathrm{X}$ & $x$ & $\mathrm{X}$ & & & $X$ & & $\mathrm{X}$ & $\mathrm{X}$ & $X$ & $X$ & $X$ \\
\hline $\begin{array}{l}\text { 10. Capacity for criticism } \\
\text { and self-criticism }\end{array}$ & & $\mathrm{X}$ & $\mathrm{X}$ & $x$ & $\mathrm{x}$ & $\mathrm{X}$ & $\mathrm{X}$ & $\mathrm{X}$ & & $x$ & $\mathrm{X}$ & $x$ & $\mathrm{X}$ & $\mathrm{X}$ & $\mathrm{X}$ & $X$ \\
\hline 11. Ability for self-learning & $\mathrm{X}$ & $\mathrm{X}$ & $\mathrm{X}$ & $\mathrm{X}$ & & & $\mathrm{X}$ & & & & & & $X$ & $\mathrm{X}$ & & \\
\hline $\begin{array}{l}\text { 12. Organisational and } \\
\text { planning skills }\end{array}$ & & $x$ & $x$ & $\mathrm{X}$ & $X$ & $\mathrm{X}$ & $\mathrm{x}$ & $\mathrm{X}$ & $x$ & $x$ & $x$ & $x$ & $\mathrm{x}$ & $x$ & $\mathrm{x}$ & $\mathrm{x}$ \\
\hline $\begin{array}{l}\text { 13. Ability to identify } \\
\text { problems }\end{array}$ & & & $\mathrm{X}$ & $\mathrm{x}$ & $\mathrm{x}$ & $\mathrm{X}$ & $x$ & $\mathrm{X}$ & $\mathrm{X}$ & $x$ & $\mathrm{X}$ & $x$ & $\mathrm{x}$ & $x$ & $\mathrm{X}$ & $\mathrm{X}$ \\
\hline $\begin{array}{l}\text { 14. Ability to resolve } \\
\text { conflicts }\end{array}$ & & & & $\mathrm{X}$ & $X$ & $\mathrm{X}$ & & $\mathrm{X}$ & $\mathrm{X}$ & $X$ & $x$ & $x$ & $\mathrm{X}$ & & $\mathrm{X}$ & K \\
\hline $\begin{array}{l}\text { 15. Ability to generate new } \\
\text { ideas (creativity) }\end{array}$ & & & & $\mathrm{x}$ & & $\mathrm{x}$ & $\mathrm{X}$ & $\mathrm{X}$ & $\mathrm{X}$ & & & $x$ & $\mathrm{X}$ & $\mathrm{X}$ & $\mathrm{X}$ & $\mathrm{X}$ \\
\hline $\begin{array}{l}\text { 16. Ability to take up new } \\
\text { initiatives }\end{array}$ & & & & $\mathrm{x}$ & $\mathrm{x}$ & $\mathrm{X}$ & $\mathrm{x}$ & & $\mathrm{X}$ & $x$ & & $x$ & $\mathrm{X}$ & $\mathrm{X}$ & & $\mathrm{X}$ \\
\hline $\begin{array}{l}\text { 17. Ability to adapt to } \\
\text { changing circumstances }\end{array}$ & $x$ & & $x$ & $\mathrm{x}$ & $x$ & $\mathrm{x}$ & & & $\mathrm{X}$ & $X$ & $x$ & $x$ & $\mathrm{x}$ & $\mathrm{X}$ & $\mathrm{X}$ & $\mathrm{X}$ \\
\hline $\begin{array}{l}\text { 18. Ability to work on } \\
\text { one's own }\end{array}$ & $\mathrm{X}$ & $\mathrm{X}$ & & $x$ & $\mathrm{x}$ & $\mathrm{x}$ & $\mathrm{X}$ & & & & & & $\mathrm{X}$ & & & \\
\hline $\begin{array}{l}\text { 19. Ability to make } \\
\text { decisions }\end{array}$ & & & & $x$ & $\mathrm{x}$ & $\mathrm{x}$ & $\mathrm{x}$ & $\mathrm{x}$ & $\mathrm{X}$ & $X$ & $\mathrm{X}$ & $x$ & $\mathrm{X}$ & $\mathrm{X}$ & $\mathrm{X}$ & $\mathrm{X}$ \\
\hline 20. Interpersonal skills & & & $\mathrm{X}$ & $\mathrm{X}$ & $\mathrm{X}$ & $\mathrm{X}$ & & $\mathrm{X}$ & $\mathrm{X}$ & $X$ & $\mathrm{X}$ & $\mathrm{X}$ & & $\mathrm{X}$ & $\mathrm{X}$ & $\bar{X}$ \\
\hline $\begin{array}{l}\text { 21. Ability to assimilate } \\
\text { and apply knowledge }\end{array}$ & $\mathrm{X}$ & $X$ & & $x$ & & $x$ & $\mathrm{X}$ & & & $x$ & $X$ & $x$ & $\mathrm{X}$ & & $\mathrm{X}$ & \\
\hline 22. Capacity for dynamism & & & & $\mathrm{X}$ & $\mathrm{X}$ & $\mathrm{X}$ & $\mathrm{X}$ & & $X$ & $\mathrm{X}$ & $\mathrm{X}$ & $\mathrm{X}$ & & $\mathrm{X}$ & $\mathrm{X}$ & $X$ \\
\hline \begin{tabular}{l|} 
23. Capacity for discipline \\
and self-control
\end{tabular} & $X$ & $x$ & $x$ & $\mathrm{x}$ & $x$ & $\mathrm{x}$ & $\mathrm{x}$ & $X$ & $\mathrm{X}$ & $\mathrm{X}$ & $\mathrm{x}$ & $x$ & $\mathrm{x}$ & $\mathrm{x}$ & $\mathrm{X}$ & $X$ \\
\hline \begin{tabular}{|l} 
24. Oral and written \\
communication in english
\end{tabular} & $X$ & $\mathrm{x}$ & & & & & & & $X$ & & & $X$ & & $\mathrm{X}$ & $x$ & $X$ \\
\hline
\end{tabular}

Table 7. Promotion of personal and professional skills according to different activities and learning situations. 


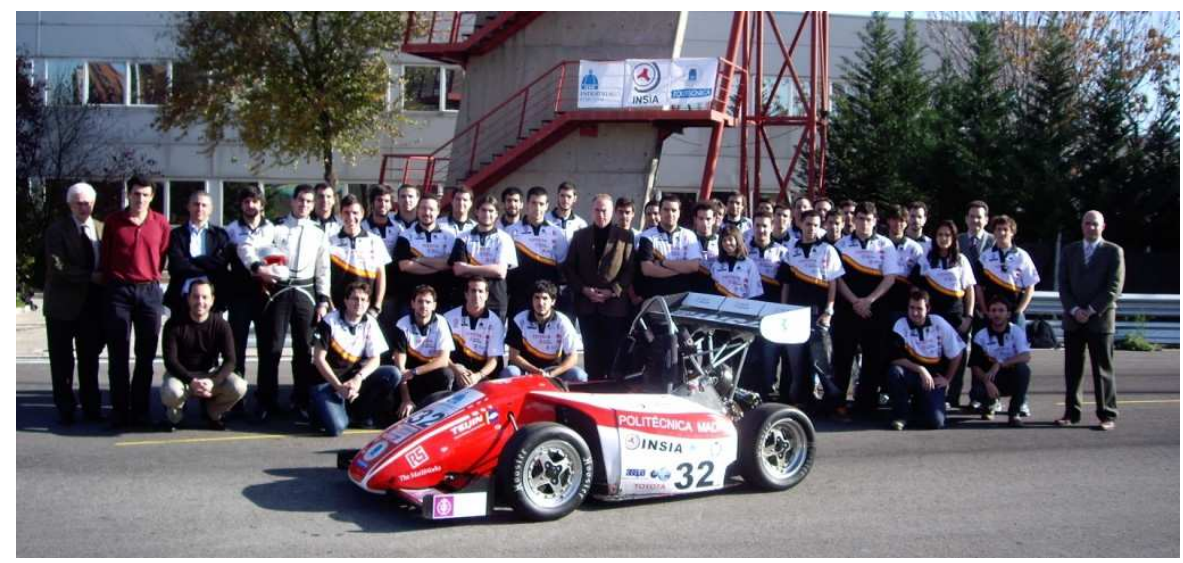

Fig. 8. Students and Faculty Advisors with the UPM'06.

To sum up, the educational experience provided by taking part in the project and the teaching methods used mean that the student must face up to specifically designed situations that will challenge them and promote their personal and professional skills. Table 7 shows 16 learning situations related to different moments or activities of the project, crossreferenced with 24 skills, which in the light of the literature consulted and the studies and surveys presented, are deemed to be the most sought after in an engineer getting ready to work in the automotive sector.

\subsection{Assessing the experience}

From the first steps of the project the faculty advisors have been interested to know the opinion of the students taking part, what needs to be kept as it is, what needs improving, and obviously, to what extent the project's goals have been achieved. And among these goals is the distinguishing improvement in students' personal and professional skills compared to traditional activities.

Every year, all the students are given a survey with the 24 most important skills for an engineer in the automotive sector in order to get to know their opinion of the importance of these skills when working in their profession, as well as the level of their success in the subjects taken as part of their degree, and likewise during the SAE Formula training process. Several conclusions can be drawn from the general results of the survey that are shown in Table 8:

- The most important skills for the participants are the capacity for responsibility and commitment, teamwork, decision making, creativity, solving conflicts and communication in English. This classification is in total harmony with the opinion of companies, which shows that the training experience suitably orients students towards the labour market, especially if we compare the results with those shown in Table 1.

- $\quad$ The students give an average score of 4.2 points out of 5 to the list of 24 skills. Their average level of success during their degree is 2.3 points, while achievement during the SAE Formula project is 3.6 points.

- $\quad$ Focusing on the 7 most appreciated skills, the average score of importance given is 4.7 points out of 5 , with a score during their degree of 1.9 points and practically double, 3.7 points for the SAE Formula project. 


\begin{tabular}{|c|c|c|c|}
\hline Skills & $\begin{array}{c}\text { Level of } \\
\text { importance } \\
\text { for students }\end{array}$ & $\begin{array}{c}\text { Degree of } \\
\text { success in } \\
\text { ETSII }\end{array}$ & $\begin{array}{c}\text { Degree of } \\
\text { success in } \\
\text { F SAE }\end{array}$ \\
\hline 1. Ability to work as part of a team & 4.9 & 2.0 & 4.1 \\
\hline 2. Leadership qualities & 4.2 & 1.1 & 3.6 \\
\hline 3. Ability to motivate & 4.4 & 1.3 & 3.8 \\
\hline $\begin{array}{l}\text { 4. Capacity for responsibility and } \\
\text { commitment }\end{array}$ & 5.0 & 3.2 & 3.8 \\
\hline 5. Ability to innovate & 4.2 & 1.3 & 3.6 \\
\hline 6. Negotiating skills & 3.6 & 1.2 & 2.8 \\
\hline 7. Capacity for self-motivation & 4.0 & 2.2 & 3.2 \\
\hline 8. Analytical skills & 4.4 & 2.8 & 3.4 \\
\hline 9. Ability to summarise & 4.0 & 3.1 & 3.3 \\
\hline 10. Capacity for criticism and self-criticism & 4.0 & 2.1 & 3.6 \\
\hline 11. Ability for self-learning & 4.2 & 3.9 & 4.3 \\
\hline 12. Organisational and planning skills & 4.0 & 3.2 & 3.2 \\
\hline 13. Ability to identify problems & 4.8 & 2,6 & 4.0 \\
\hline 14. Ability to resolve conflicts & 4.4 & 1.9 & 3.3 \\
\hline 15. Ability to generate new ideas (creativity) & 4.4 & 1.3 & 3.6 \\
\hline 16. Ability to take up new initiatives & 3.7 & 1.3 & 3.3 \\
\hline $\begin{array}{l}\text { 17. Ability to adapt to changing } \\
\text { circumstances }\end{array}$ & 4.1 & 2.7 & 3.9 \\
\hline 18. Ability to work on one's own & 3.4 & 3.8 & 3.2 \\
\hline 19. Ability to make decisions & 4.9 & 2.0 & 4.0 \\
\hline 20. Interpersonal skills & 3.8 & 2.7 & 4.3 \\
\hline $\begin{array}{l}\text { 21. Ability to assimilate and apply } \\
\text { knowledge }\end{array}$ & 4.1 & 3.0 & 4.0 \\
\hline 22. Capacity for dynamism & 3.8 & 2.0 & 3.7 \\
\hline 23. Capacity for discipline and self-control & 3.8 & 3.0 & 3.3 \\
\hline $\begin{array}{l}\text { 24. Oral and written communication in } \\
\text { English }\end{array}$ & 4.4 & 1.6 & 3.1 \\
\hline Mean value & 4,2 & 2,3 & 3,6 \\
\hline
\end{tabular}

Table 8. Scores from 0 to 5 points of the importance given by students to the 24 most important personal and professional skills for an engineer in the automotive sector, as well as the extent of success during their degree at the School of Industrial Engineers (ETSIIUPM) and during their time on the project (F SAE).

As can be seen, the students find their way through the competition has contributed to the promotion of their personal and professional skills more than the rest of the activities carried out during his career in engineering. This assessment is certainly influenced, year after year, for the interest they awakened this activity, but it has been shown in both the UPM and in other participating universities, the great importance that these competitions have in the integral formation of engineering students before they enter the job market. And this importance is even greater if the sector that leads the student is the automotive. 


\section{Conclusions}

In this paper it has been described the growing importance given by leading universities to improving the skills of their students, beyond mere theoretical - practical knowledge.

In this way, different automotive competitions for engineering universities round the world are presented, analyzing their objectives, work to be performed by the students, tests, etc.

A growing number of these leading technical universities consider them very useful activities for the improvement of those desired skills.

The paper presents as well, the way the first university in Spain (ETSII-UPM) that competed in the most complete of these competition (Formula SAE) manage their students on it, how the competition is integrated into their own academic programs, and the assessment of their experience in terms of personal and professional skills' improvement among their students. Surveys of student conducted each year show that they consider that taking part on one of this competition has more contributed to the improvement of their personal and professional abilities and skills than the rest of the activities done during the whole career of five years.

Students, teachers and company employers around the world agree that this competitions promote careers and excellence in engineering as it encompasses all aspects of the automotive industry including research, design, manufacturing, testing, developing, marketing, management and finances. They take students out of the classroom and allow them to apply textbook theories to real work experiences.

\section{References}

Aparicio, F., González, R.M., Sobrevila, M.A. (2005). Formación de Ingenieros. Objetivos, métodos y estrategias, Instituto de Ciencias de la Educación, UPM.

Bolívar, C., Más allá de la formación: el desarrollo de competencias. (2001). http://www.arearh.com/formación/masallaformacion.htm.

Bologna Declaration. (1999). Joint declaration of the European Ministers of Education, 19th June.

Bowen, E., Lloyd, S. and Thomas, S. (2005). Embedding Personal Development Planning into the Curriculum Via a Key Skills Assignment, Int. J. Engineering Education. Vol. 21, No. 6, pp. $1159 \pm 1167$.

Chadha, D. and Nicholls, G. (2006). Teaching Transferable Skills to Undergraduate Engineering Students: Recognising the Value of Embedded and Bolt-on Approaches, Int. J. Engng Ed. Vol. 22, No. 1, pp. 116 \pm 122 .

Davies, H. A., Csete, J. and Poon, L. K. (1999). Employer's Expectations of the Performance of Construction Graduates, Int. J. Engineering Education. Vol. 15, No. 3, pp. 191-198,

De Miguel, M., Alfaro, I.J., Apocada, P.M., Arias, J.M., García, E., Lobato, C. and Pérez, A. (2006). Metodologías de enseñanza y aprendizaje para el desarrollo de competencias. Madrid: Alianza Editorial.

European Parliament. (2006). Recommendation 2006/962/EC of the European Parliament and of the Council on key competences for lifelong learning: OJ L 394, 30.12.2006; Bull. 12

González, J., Wagenaar, R. (2003). Tuning Educational Structures in Europe. Universidad de Deusto,. 
Sánchez, F.J., Aparicio, F., Álvarez, M.A. and Jiménez, F. (2009). SAE Formula Project for Developing Personal and Professional Skills in Automotive Engineers, Int. J. Engineering Education. Vol. 25, No. 3, pp. 585-594.

http://students.sae.org/competitions/bajasae/ http://students.sae.org/competitions/formulaseries/ http:/ / students.sae.org/competitions/supermileage/

http://www.globalgreenchallenge.com.au/

http://www.kartlowcost.com/Presentation.html

http://www.shell.com/home/content/ecomarathon/ 


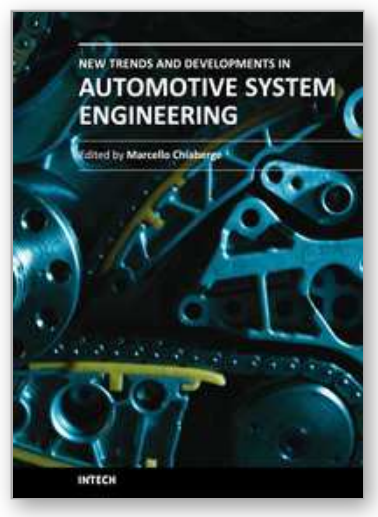

\author{
New Trends and Developments in Automotive System Engineering \\ Edited by Prof. Marcello Chiaberge
}

ISBN 978-953-307-517-4

Hard cover, 664 pages

Publisher InTech

Published online 08, January, 2011

Published in print edition January, 2011

In the last few years the automobile design process is required to become more responsible and responsibly related to environmental needs. Basing the automotive design not only on the appearance, the visual appearance of the vehicle needs to be thought together and deeply integrated with the â€œpowerâ€ developed by the engine. The purpose of this book is to try to present the new technologies development scenario, and not to give any indication about the direction that should be given to the research in this complex and multi-disciplinary challenging field.

\title{
How to reference
}

In order to correctly reference this scholarly work, feel free to copy and paste the following:

Francisco J. Sánchez-Alejo, Miguel A. Alvarez, Francisco Aparicio and José M. López (2011). Analysis Approach of How University Automotive Competitions Help Students to Accelerate their Automotive Engineer Profile, New Trends and Developments in Automotive System Engineering, Prof. Marcello Chiaberge (Ed.), ISBN: 978-953-307-517-4, InTech, Available from: http://www.intechopen.com/books/new-trends-anddevelopments-in-automotive-system-engineering/analysis-approach-of-how-university-automotivecompetitions-help-students-to-accelerate-their-automo

\section{INTECH}

open science | open minds

\section{InTech Europe}

University Campus STeP Ri

Slavka Krautzeka 83/A

51000 Rijeka, Croatia

Phone: +385 (51) 770447

Fax: +385 (51) 686166

www.intechopen.com

\section{InTech China}

Unit 405, Office Block, Hotel Equatorial Shanghai

No.65, Yan An Road (West), Shanghai, 200040, China

中国上海市延安西路65号上海国际贵都大饭店办公楼405单元

Phone: +86-21-62489820

Fax: +86-21-62489821 
(C) 2011 The Author(s). Licensee IntechOpen. This chapter is distributed under the terms of the Creative Commons Attribution-NonCommercialShareAlike-3.0 License, which permits use, distribution and reproduction for non-commercial purposes, provided the original is properly cited and derivative works building on this content are distributed under the same license. 